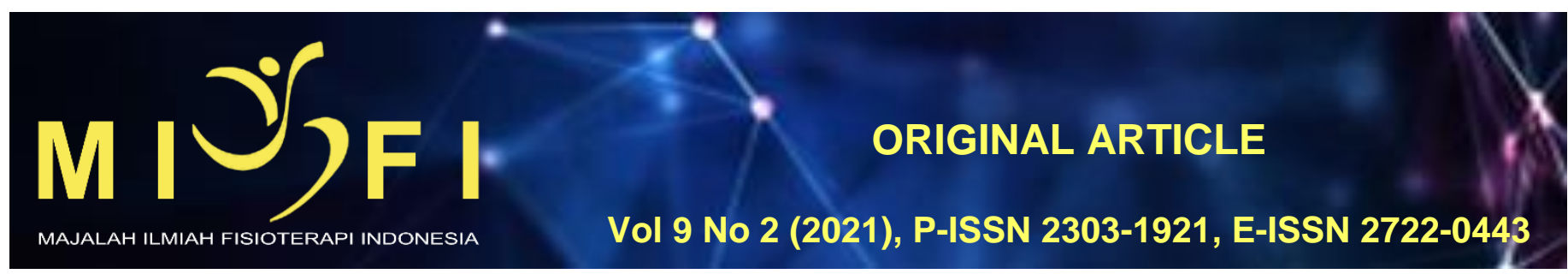

\title{
LEG SQUAT EXERCISE LEBIH EFEKTIF DIBANDINGKAN PELATIHAN LARI 100 METER TERHADAP PENINGKATAN KEKUATAN OTOT TUNGKAI PADA PEMAIN BULUTANGKIS
}

\author{
Ketut Trisandy ${ }^{1}$, Ni Wayan Tianing ${ }^{2}$, Made Hendra Satria Nugraha ${ }^{3}$, I Made Muliarta ${ }^{4}$ \\ ${ }^{1}$ Program Studi Sarjana Fisioterapi dan Profesi Fisioterapi, Fakultas Kedokteran Universitas Udayana, Denpasar, Bali \\ 2Departemen Biokimia, Fakultas Kedokteran Universitas Udayana, Denpasar, Bali \\ ${ }^{3}$ Departemen Fisioterapi, Fakultas Kedokteran Universitas Udayana, Denpasar, Bali \\ ${ }^{4}$ Departemen Faal, Fakultas Kedokteran, Universitas Udayana, Denpasar, Bali \\ tri sandy25@yahoo.com
}

\begin{abstract}
ABSTRAK
Kekuatan otot adalah kemampuan otot untuk menghasilkan tenaga yang berperan mengatasi sebuah tahanan atau beban dalam menjalankan suatu aktivitas. Kekuatan otot tungkai merupakah salah satu aspek fisik yang harus dimiliki oleh seorang pemain bulutangkis yang berpengaruh terhadap footwork para pemain bulutangkis dan berdampak pada prestasi dan performa permainan. Tujuan penelitian ini adalah untuk mengetahui apakah efek pelatihan leg squat exercise lebih baik dalam meningkatkan kekuatan otot tungkai dibandingkan dengan pelatihan lari 100 meter. Penelitian ini bersifat eksperimental dengan menggunakan rancangan Pre and Post Test Control Group Design. Sampel penelitian berjumlah 34 orang yang dibagi menjadi 2 kelompok, yaitu kelompok kontrol yang diberikan pelatihan lari 100-meter dan kelompok perlakuan yang diberikan pelatihan leg squat exercise. Hasil menunjukkan adanya peningkatan kekuatan otot tungkai pada kelompok kontrol sebesar 3,23 dan pada kelompok perlakuan terjadi peningkatan kekuatan otot tungkai sebesar 5,28 . Uji paired sample $t$-test didapatkan perbedaan yang signifikan dengan nilai $p=0,000(p<0,05)$ pada kelompok kontrol dan nilai $\mathrm{p}=0,000(\mathrm{p}<0,05)$ pada kelompok perlakuan. Uji beda selisih dengan independent $t$ test menunjukkan adanya perbedaan yang bermakna antara kelompok kontrol dan kelompok perlakuan dimana $p=0,001$ $(p<0,05)$. Pelatihan leg squat exercise lebih efektif dalam meningkatkan kekuatan otot tungkai daripada pelatihan lari 100-meter terhadap pemain bulutangkis.
\end{abstract}

Kata kunci: kekuatan, otot, leg squat exercise, lari 100 meter, bulutangkis.

\section{LEG SQUAT EXERCISE IS MORE EFFECTIVE THAN 100 METERS RUNNING TRAINING ON IMPROVING THE STRENGTH OF LEG MUSCLE IN BADMINTON PLAYERS}

\section{ABSTRACT}

Muscle strength is the ability of muscles to produce energy that plays a role in overcoming a prisoner or burden in carrying out an activity. Leg muscle strength is one of the physical aspects that must be possessed by a badminton player which affects the footwork of badminton players and has an impact on the performance and performance of the game. The purpose of this study was to determine the effect of better leg squat exercise training in increasing leg muscle strength compared to 100 meter running training. This research is an experimental study using the Pre and Post Test Control Group Design. The research sample consisted of 34 people who were divided into 2 groups, namely the control group who were given 100 meter running training and the treatment group who were given leg squat exercise training. The results showed an increase in leg muscle strength in the control group by 3.23 and in the treatment group an increase in leg muscle strength was 5.28. Paired sample t-test results obtained a significant difference with the value of $p=0,000(p<0.05)$ in the control group and the value of $p=0,000(p<0.05)$ in the treatment group. Difference test with independent t-test showed a significant difference between the control group and the treatment group $p=0.001$ $(p<0.05)$. Leg squat exercise training is more effective in increasing leg muscle strength than 100 meter running training for badminton players

Keywords: strength, muscle, leg squat exercise, running 100 meters training, badminton.

\section{PENDAHULUAN}

Olahraga merupakan suatu aktivitas yang teratur untuk mendorong, membina, serta mengembangkan potensi dari jasmani, rohani, dan sosial individu. Olahraga mampu menumbuhkan kesempatan yang ideal untuk menyalurkan energi yang positif dalam lingkungan persaudaraan dan persahabatan guna menciptakan persatuan yang sehat, suasana yang akrab dan gembira, menuju kehidupan serasi, selaras, dan seimbang untuk mencapai kebahagiaan hidup yang sejati. ${ }^{1}$ Salah satu olahraga yang paling diminati oleh masyarakat perkotaan hingga desa, mulai anak-anak hingga dewasa adalah olahraga bulutangkis. Bulutangkis merupakan olahraga yang bersifat individual yang dapat dilakukan dengan cara satu orang melawan satu orang atau kelompok ganda dua orang melawan dua orang dengan menggunakan berbagai teknik. Olahraga bulutangkis merupakan olahraga yang sangat eksplosif dan melibatkan teknik gerakan yang tidak biasa serta kekuatan di lapangan yang relatif kecil ditunjang dengan kondisi fisik, sikap mental, keberanian, kecerdasan dan keterampilan teknis pemain serta efisiensi taktis. ${ }^{2,3}$ 
Derajat kondisi fisik yang prima merupakan faktor penting yang harus dimiliki oleh setiap pemain bulutangkis. Hal tersebut menyebabkan pemain bulutangkis perlu dalam peningkatan kelincahan, daya tahan otot lokal, daya tahan cardiovascular, kekuatan otot, power, kecepatan, dan komposisi tubuh. Kekuatan otot merupakan kemampuan dari otot yang menghasilkan tegangan dan tenaga yang berperan untuk mengatasi sebuah tahanan atau beban dalam menjalankan suatu aktivitas. ${ }^{4,5}$ Kekuatan pada otot tungkai merupakan suatu kekuatan yang paling berpengaruh dalam permainan bulutangkis. Hal tersebut dikarenakan kekuatan otot merupakan dasar dari daya ledak dan daya tahan otot. Kekuatan otot yang kurang baik oleh pemain bulutangkis, menyebabkan daya ledak untuk melakukan gerakan smash menjadi buruk. ${ }^{6}$

Latihan seperti squat exercise dan lari merupakan intervensi yang sering dilakukan oleh fisioterapi untuk meningkatkan kekuatan otot. Kemudahan dalam pemberian latihan, pembiayaan yang tidak terlalu besar serta berkaitan dengan pergerakan pada teknik-teknik dasar bulutangkis ketika melakukan footwork menyebabkan squat exercise dan latihan lari menjadi latihan yang umumnya digunakan oleh fisioterapi. Squat exercise adalah jenis latihan beban yang berguna dalam meningkatkan atau mengembangkan kekuatan otot terutama pada kelompok otot di bagian tungkai karena menggunakan beban tubuh sebagai dasar pokok latihan. Squat exercise termasuk kedalam jenis latihan closed kinetic chain, yaitu suatu bentuk latihan statik yang dilakukan ketika otot berkontraksi namun tanpa gerakan anggota tubuh. ${ }^{7}$ Lari adalah gerakan dinamis dengan langkah-langkah, dengan cara satu kaki diluruskan dan diangkat menjadi gerakan melayang kemudian disusul dengan pendaratan di tanah pada kaki yang lainnya. Semakin sering melakukan latihan lari, khususnya lari jarak dekat seperti lari 100 meter, membuat otot akan semakin eksplosif. Hal ini mengakibatkan meningkatnya daya ledak pada otot yang berbanding lurus dengan meningkatnya kekuatan otot tersebut. ${ }^{8,9}$

Berdasarkan latar belakang di atas, untuk itu peneliti mencoba untuk melakukan penelitian penanganan fisioterapi pada peningkatan kekuatan otot tungkai yang berjudul "Leg Squat Exercise Lebih Efektif Dibandingkan Pelatihan Lari 100 Meter Terhadap Peningkatan Kekuatan Otot Tungkai Pada Pemain Bulutangkis”.

\section{METODE PENELITIAN}

Penelitian yang dilakukan menggunakan metode eksperimental, dengan memakai kelompok kontrol. Rancangan penelitian menggunakan two group pre and post test control group design. Untuk mengetahui makna pemberian leg squat exercise dan latihan lari 100 meter terhadap peningkatan kekuatan otot tungkai pada pemain bulutangkis. Penelitian ini dilakukan di Gelanggang Olahraga Porwaja Denpasar kepada 34 pemain bulutangkis remaja. Penelitian dilaksanakan pada bulan Maret-April 2020. Penelitian dilakukan 2 kali per minggu selama 4 minggu. Teknik pengambilan subjek dengan cara simple random yang memenuhi kriteria inklusi dan eksklusi.

Kriteria inklusi: Bersedia sebagai subjek penelitian dari awal hingga akhir, dengan mengisi informed consent, remaja yang tergabung dalam persatuan bulutangkis, remaja yang telah berusia 10 - 15 tahun, dan remaja dengan IMT normal. Kriteria eksklusi: Sebelumnya pernah mengalami cedera pada tungkai, terdapat keterbatasan pada luas gerak sendi tungkai, mengalami nyeri pada ekstremitas atas maupun ekstremitas bawah, dan memiliki riwayat gangguan jantung atau pernapasan.

Pengukuran kekuatan otot tungkai sebelum dan setelah diberikan leg squat exercise dan pelatihan lari 100 meter menggunakan leg dynamometer.

\section{HASIL PENELITIAN \\ Karakteristik Sampel Penelitian}

Karakteristik sampel penelitian berdasarkan usia dan jenis kelamin dari subjek seperti yang dijabarkan pada Tabel 1.

Tabel 1. Karakteristik Sampel Penelitian Berdasaran Jenis Kelamin

\begin{tabular}{|c|c|c|c|c|}
\hline & \multicolumn{2}{|c|}{ Frekuensi } & \multicolumn{2}{|c|}{ Persentase } \\
\hline & Kelompok Kontrol & Kelompok Perlakuan & Kelompok Kontrol & Kelompok Perlakuan \\
\hline Laki-laki & 14 & 10 & 82,3 & 58,8 \\
\hline Perempuan & 3 & 7 & 17,7 & 41,2 \\
\hline Total & 17 & 17 & 100 & 100 \\
\hline
\end{tabular}

Berdasarkan Tabel 1 menunjukkan bahwa total subjek penelitian berjumlah 34 subjek yang terdiri dari 2 kelompok dengan masing-masing kelompok berjumlah 17 subjek. Kelompok kontrol yang berjenis kelamin laki-laki sebanyak 14 subjek (82,3\%) dan berjenis kelamin perempuan sebanyak 3 subjek (17,7\%). Sedangkan pada kelompok perlakuan yang berjenis kelamin laki-laki sebanyak 10 subjek $(58,8 \%)$ dan berjenis kelamin perempuan sebanyak 7 subjek $(41,2 \%)$.

Karakteristik subjek penelitian berupa umur dan Indeks Massa Tubuh (IMT) pada kedua kelompok dipaparkan dalam Tabel 2.

Tabel 2. Karakteristik Subjek Penelitian Berdasaran Indeks Massa Tubuh (IMT)

\begin{tabular}{ccccc}
\hline \multirow{2}{*}{ Karakteristik } & \multicolumn{4}{c}{ Kilai Rerata dan Simpang Baku } \\
& Rerata & $\begin{array}{c}\text { Simpang } \\
\text { Baku }\end{array}$ & Rerata & $\begin{array}{c}\text { Simpang } \\
\text { Baku }\end{array}$ \\
\hline Usia & 12,53 & 1,87 & 11,94 & 1,63 \\
IMT (Normal) & 20,04 & 1,25 & 20,27 & 1,23 \\
\hline
\end{tabular}


Berdasarkan Tabel 2 menunjukkan bahwa subjek penelitian kelompok kontrol memiliki rerata usia (12,53) tahun dan pada kelompok perlakuan memiliki rerata umur $(11,94)$ tahun. IMT pada kelompok kontrol didapatkan rerata $(20,04)$ dan pada kelompok perlakuan $(20,27)$.

Uji normalitas dan uji homogenitas data sebelum dan sesudah pelatihan dilakukan karena merupakan prasyarat untuk menentukan uji statistik yang akan digunakan dalam penelitian ini. Uji normalitas dengan menggunakan Shapiro Wilk Test, sedangkan uji homogenitas dengan menggunakan Levene's Test. Hasil dari analisis uji tersebut tercantum pada Tabel 3.

Tabel 3. Hasil Uji Normalitas dan Homogenitas Peningkatan Kekuatan Otot Tungkai Sebelum dan Sesudah Pelatihan

\begin{tabular}{|c|c|c|c|c|c|c|c|}
\hline \multicolumn{8}{|c|}{ Uji Normalitas dengan Shapiro Wilk Test } \\
\hline \multirow{2}{*}{ Kelompok Data } & \multicolumn{3}{|c|}{ Kelompok Kontrol } & \multicolumn{3}{|c|}{ Kelompok Perlakuan } & \multirow{2}{*}{$\begin{array}{l}\text { Uji Homogenitas } \\
\text { (Levene's Test) }\end{array}$} \\
\hline & Rerata & $\begin{array}{c}\text { Simpang } \\
\text { baku }\end{array}$ & $\mathrm{p}$ & Rerata & $\begin{array}{c}\text { Simpang } \\
\text { baku }\end{array}$ & $\mathrm{p}$ & \\
\hline $\begin{array}{l}\text { Skor Kekuatan Otot } \\
\text { Sebelum Pelatihan }\end{array}$ & 27,76 & 13,63 & 0,613 & 21,64 & 12,34 & 0,201 & 0,049 \\
\hline $\begin{array}{l}\text { Skor Kekuatan Otot } \\
\text { Sesudah Pelatihan }\end{array}$ & 31,00 & 13,66 & 0,648 & 27,23 & 12,81 & 0,237 & 0,068 \\
\hline
\end{tabular}

Berdasarkan Tabel 3 menunjukkan hasil uji normalitas dengan menggunakan Shapiro Wilk Test pada kelompok kontrol sebelum pelatihan didapatkan nilai $p=0,613(p>0,05)$ dan setelah pelatihan didapatkan nilai $p=0,648(p>$ $0,05)$ sedangkan pada kelompok perlakuan sebelum pelatihan didapatkan nilai $p=0,201(p>0,05)$ dan setelah penelitian didapatkan nilai $p=0,237(p>0,05)$. Hasil tersebut menunjukkan bahwa data kekuatan otot sebelum dan sesudah penelitian pada kelompok kontrol dan kelompok perlakuan berdistribusi normal.

Uji homogenitas dalam tabel diatas menggunakan Levene's Test yang menunjukkan nilai $p=0,049(p>0,05)$ untuk data kekuatan otot sebelum pelatihan, dan nilai $p=0,068(p>0,05)$ untuk data kekuatan otot sesudah pelatihan. Pengujian data kekuatan otot sebelum dan sesudah pelatihan menunjukkan data yang tidak homogen.

Pengujian perbedaan rerata peningkatan nilai kekuatan otot sebelum dan setelah intervensi pada kelompok kontrol dan kelompok perlakuan diuji dengan uji Paired Sample T-test. Uji Paired Sample T-test bertujuan untuk mengetahui perbedaan rerata peningkatan nilai kekuatan otot sebelum dan setelah intervensi. Hasil uji Paired Sample T-test tercantum pada Tabel 4.

Tabel 4. Hasil Uji Paired Sample T-test

\begin{tabular}{|c|c|c|c|c|c|c|c|}
\hline & \multirow{2}{*}{$\begin{array}{c}\text { Rerata Sebelum } \\
\text { Pelatihan }\end{array}$} & \multirow{2}{*}{$\begin{array}{c}\text { Rerata Sesudah } \\
\text { Pelatihan }\end{array}$} & \multirow{2}{*}{$\begin{array}{l}\text { Beda } \\
\text { Rerata }\end{array}$} & \multirow{2}{*}{$\begin{array}{c}\text { Simpang } \\
\text { baku }\end{array}$} & \multicolumn{2}{|c|}{$95 \% \mathrm{Cl}$} & \multirow[b]{2}{*}{$p$} \\
\hline & & & & & Lower & Upper & \\
\hline $\begin{array}{c}\text { Kelompok } \\
\text { Kontrol }\end{array}$ & 27,76 & 31,00 & 3,23 & 1,88 & $-4,206$ & $-2,264$ & 0,000 \\
\hline $\begin{array}{l}\text { Kelompok } \\
\text { Perlakuan }\end{array}$ & 21,64 & 27,23 & 5,58 & 2,00 & $-6,617$ & $-4,558$ & 0,000 \\
\hline
\end{tabular}

Berdasarkan Tabel 4 didapatkan hasil pada beda rerata peningkatan nilai kekuatan otot yang dilakukan analisis dengan paired sample $t$-test sebelum dan setelah intervensi pada kelompok kontrol dengan nilai $p=0,000(p<0,05)$ mengartikan bahwa terdapat perbedaan yang bermakna pada peningkatan nilai kekuatan otot sebelum dan setelah pelatihan lari 100 meter pada pemain bulutangkis di GOR Porwaja Denpasar.

Analisis Uji paired sample t-test pada kelompok perlakuan sebelum dan sesudah pelatihan menunjukkan nilai $p=0,000(p<0,05)$ yang berarti ada perbedaan yang signifikan pada peningkatan kekuatan otot sebelum dan sesudah diberikan leg squat exercise pada pemain bulutangkis di GOR Porwaja Denpasar.

Tabel 5. Hasil Uji Independent Sample T-test

\begin{tabular}{|c|c|c|c|c|c|c|c|c|}
\hline & \multirow{2}{*}{ Kelompok } & \multirow{2}{*}{$\mathrm{N}$} & \multirow{2}{*}{ Rerata } & \multirow{2}{*}{ Simpang baku } & \multirow{2}{*}{$\mathrm{t}$} & \multicolumn{2}{|c|}{$95 \% \mathrm{Cl}$} & \multirow[b]{2}{*}{$p$} \\
\hline & & & & & & Lower & Upper & \\
\hline \multirow{2}{*}{ Pre-test } & Kelompok Kontrol & 17 & 27,76 & 13,63 & \multirow{2}{*}{1,37} & \multirow{2}{*}{$-2,9$} & \multirow{2}{*}{15,2} & \multirow{2}{*}{0,18} \\
\hline & Kelompok Perlakuan & 17 & 21,64 & 12,34 & & & & \\
\hline Post-test & $\begin{array}{c}\text { Kelompok Kontrol } \\
\text { Kelompok Perlakuan }\end{array}$ & $\begin{array}{l}17 \\
17\end{array}$ & $\begin{array}{l}31,00 \\
27,23\end{array}$ & $\begin{array}{l}13,66 \\
12,81\end{array}$ & 0.82 & $-5,4$ & 13,02 & 0,41 \\
\hline Selisih & $\begin{array}{l}\text { Kelompok Kontrol } \\
\text { Kelompok Perlakuan }\end{array}$ & $\begin{array}{l}17 \\
17\end{array}$ & $\begin{array}{l}3,25 \\
5,59 \\
\end{array}$ & $\begin{array}{l}1,88 \\
2,00\end{array}$ & $-3,5$ & $-3,7$ & $-0,99$ & 0,001 \\
\hline
\end{tabular}

Berdasarkan Tabel 5 yang memperlihatkan hasil dari pengujian menggunakan independent sample $t$-test untuk mengetahui ada tidaknya perbedaan yang signifikan pada nilai kekuatan otot antara kedua kelompok sebelum pelatihan (pre-test) dan setelah pelatihan (post-test). Hasil pengujian pre-test menunjukkan nilai $p=0,18(p>0,05)$ yang berarti tidak ada perbedaan yang signifikan dalam rerata nilai kekuatan otot antara kedua kelompok. Sedangkan pengujian independent sample t-test dilakukan pada data hasil rerata nilai kekuatan otot antara kedua kelompok setelah pelatihan (post-test) menunjukkan $p=0,41$ ( $p>0,05)$ yang berarti tidak ada perbedaan yang signifikan dalam rerata nilai kekuatan otot antara kedua kelompok. Sehingga dilakukan perhitungan beda rerata pada selisih antara sebelum dan sesudah pelatihan. Hasil yang didapatkan diperoleh nilai $p=0,001(p>0,05)$. Hal ini menunjukkan adanya perbedaan yang bermakna di antara kedua pelatihan. 
Rerata peningkatan nilai kekuatan otot pada kelompok perlakuan lebih besar daripada kelompok kontrol. Dengan demikian, dapat dikatakan bahwa pelatihan kelompok perlakuan menghasilkan peningkatan nilai kekuatan otot lebih besar daripada pelatihan kelompok kontrol.

\section{PEMBAHASAN \\ Karakteristik Sampel}

Kekuatan otot pada pemain bulutangkis merupakan salah satu fungsi penting yang harus dimiliki, karena disamping faktor-faktor lainnya, hampir setiap gerakan dalam olahraga bulutangkis memerlukan kekuatan otot. Melindungi dari kemungkinan cedera juga menjadi salah satu peranan penting kekuatan otot. Anak-anak yang mengalami masa puber (usia 8-15 tahun), mengalami peningkatan kekuatan otot yang signifikan dan akan terus meningkat setelah masa puber. Klasifikasi usia anak untuk melakukan latihan kekuatan otot pada spesialisasi olahraga. Anak-anak direkomendasikan untuk mulai melakukan latihan kekuatan otot pada usia 7-14 tahun, dan akan mencapai puncak peningkatan kekuatan otot pada usia 15-16 tahun. ${ }^{10,11}$ Setelah masa puber, seiring bertambahnya usia kekuatan otot akan berkurang secara bertahap. Perubahan yang terjadi pada morfologis otot juga dapat menyebabkan perubahan fungsional otot, yakni kekuatan otot mengalami penurunan, elastisitas dan fleksibilitas otot menurun, terjadi penurunan pada kecepatan waktu reaksi dan rileksasi, dan kinerja fungsional. Akibat dari penurunan fungsi dan kekuatan otot akan terjadi penurunan keseimbangan tubuh, hambatan pada posisi gerak duduk ke berdiri, resiko jatuh mengalami peningkatan, dan terjadi perubahan postur. ${ }^{12}$

Kekuatan otot juga dipengaruhi oleh nilai IMT, subjek yang memiliki nilai IMT tinggi memiliki kemungkinan jumlah massa otot yang besar. Massa otot yang besar dapat meningkatkan kekuatan otot yang dihasilkan oleh tubuh. Terjadi peningkatan kekuatan otot sebesar $0,22 \mathrm{~kg}$ setiap peningkatan nilai IMT sebesar $1 \mathrm{~kg} / \mathrm{m}^{2} .{ }^{13} \mathrm{Hasil}$ analisis karakteristik subjek penelitian pada kedua kelompok tidak ada perbedaan bermakna karena subjek telah dikontrol berdasarkan usia dan IMT. Karakteristik antara kedua kelompok tersebut sama sehingga karakteristik usia dan IMT tidak lagi mempengaruhi hasil penelitian. Apabila setelah pelatihan yang dilakukan selama empat minggu ada perbedaan pada hasil kelompok pelatihan, hal ini diakibatkan dari pelatihan yang diberikan pada masing-masing kelompok.

\section{Peningkatan Kekuatan Otot Tungkai pada Kelompok Pelatihan Lari 100 Meter}

Otot memiliki satuan unit terkecil yang disebut dengan myofibril jika dilihat dari strukturnya. Serat otot terbentuk dari kumpulan myofibril tersebut. Secara anatomi, di dalam myofibril terdapat filamen-filamen untuk kontraksi otot. Terdapat filamen tipis yang disebut aktin dan filament tebal disebut myosin. Otot akan mengalami kontraksi saat berlari. Kontraksi yang terjadi tersebut terbagi atas kontraksi isometrik dan isotonik. Kontraksi isometrik melakukan kontraksi tanpa terjadi sliding filament, sedangkan kontraksi isotonik mengakibatkan pemendekkan pada otot tetapi tegangan otot tetap stabil. Ketika berlari, akan terjadi mekanisme kontraksi diantara keduanya. Kontraksi isometrik bertugas dalam usaha mempertahankan tungkai dan kontraksi isotonik akan menggerakkan tungkai dalam berlari. ${ }^{14,15}$

Saat lari 100 meter, otot akan mengalami peningkatan massa total. Dalam pelatihan ini, akan terjadi hypertrophy pada otot yang merupakan proses peningkatan jumlah filamen aktin dan myosin yang mengakibatkan terjadinya pembesaran pada serabut otot. Ketika melakukan kontraksi, otot akan membutuhkan energi berupa ATP. Pembentukan ATP diawali pada proses glikolisis dengan melakukan pemecahan molekul glukosa. Proses tersebut mengubah glukosa menjadi asam piruvat pada akhir prosesnya. Pada proses dalam tahap 1,3-difofogliserat dengan 3-asam fosfogiserat serta proses diantara asam fosfoenolpiruvat dengan asam piruvat terbentuk ATP sebagai hasil dari pembebasan energi. Sebanyak 4 molekul akan terbentuk dari seluruh total ATP. Tetapi dalam pembentukan 1,6-difosfat sebelum glikolisi digunakan 2 molekul ATP. Oleh sebab itu proses glikolisis menghasilkan 2 ATP. Setelah proses glikolisis, apabila asam piruvat telah terbentuk, proses selanjutnya yakni dekarboksilasi oksidatif. Proses ini menyebabkan asam piruvat mengalami dekarboksilasi dan akan diubah menjadi asetil-Koa. Jika asetil-Koa sudah terbentuk, proses selanjutnya yakni siklus krebs dan siklus asam sitrat. Akhir dari satu putaran siklus krebs menghasilkan 12 molekul ATP yang digunakan sebagai energi ketika kontraksi otot. ${ }^{15,16}$

Kontraksi pada otot akan terjadi jika terjadi pelepasan asetilkolin. Laju penggabungan vesikel asetilkolin dan menimbulkan eksositosis asetilkolin ke dalam ruang sinaps akan meningkat seiring dengan peningkatan konsentrasi ion $\mathrm{Ca}^{2}+$ di dalam membran terminal. Kanal asetilkolin yang terbuka akan memungkinkan ion positif yang penting seperti natrium $(\mathrm{Na}+)$, kalium $(\mathrm{K}+)$, dan kalsium $\left(\mathrm{Ca}^{2}+\right)$ untuk dapat bergerak mudah melewatinya. Peristiwa tersebut akan menciptakan suatu perubahan potensial positif setempat di dalam membran serabut otot yang disebut potensial end plate dan akan menimbulkan suatu potensial aksi yang menyebar di sepanjang membran otot. ${ }^{17,18}$ Asetilkolin dan reseptor akan berikatan di neuromuskular junction yang mengakibatkan potensial aksi. Selanjutnya akan menyebabkan terbukanya kanal voltasi kalsium kareja potensial aksi sampai di terminal akson. Ketika kanal tersebut terbuka, maka terjadi pemasukan kalsium yang akhirnya berikatan dengan troponin dan membuat tropomiosin membuka penutup dari tempat pengikatan jembatan silang di aktin. Jembatan silang myosin akan berikatan dengan aktin dan menarik sarkomer aktin hingga menuju bagian dari sarkomer. Proses tarik menarik antara aktin dan myiosin akan menyebabkan kontraksi otot. Saat potensial aksi tidak lagi ada, kalsium akan terlepas dari troponin dan diserap kembali. Setelah itu tropomiosin akan kembali ke posisi semula untuk menutup tempat pengikatan di aktin karena akibat dari lepasnya kalsium dari troponin dan kontraksi pun selesai. ${ }^{14}$

Pada saat melakukan latihan lari 100 meter, otot akan dipaksa berkontraksi untuk menguatkan dan menggerakkan otot tungkai hingga mencapai garis finish. Jika otot tungkai terus menerus melakukan kontraksi, maka unsur kontraktil seperti aktin dan myosin akan bertambah di dalam otot, serta jumlah jaringan ikat di dalam otot dan jumlah kapiler akan bertambah yang menyebabkan terjadinya hypertrophy pada otot. Hal tersebut menyebabkan meningkatnya kekuatan otot dan tahan terhadap regangan. ${ }^{19}$ 


\section{Peningkatan Kekuatan Otot Tungkai pada Kelompok Pelatihan Leg Squat Exercise}

Latihan leg squat exercise mampu meningkatkan kekuatan pada otot tungkai karena memiliki beban yang digunakan sebagai dasar pokok latihan. Pelatihan leg squat exercise bekerja dengan cara membebani organ tubuh dengan intensitas, set, frekuensi dan lama latihan serta menyebabkan timbulnya suatu efek yakni berupa kekuatan otot yang meningkat, dan peningkatan daya ledak serta daya tahan otot. Peningkatan aspek tersebut pada otot, menyebabkan kemampuan fisik akan bertambah secara umum. Pelatihan beban menggunakan beban luar berupa beban mesin atau beban bebas (barbell dan dumbbell) secara dominan bertujuan untuk meningkatkan kinerja dan prestasi olahraga dengan melakukan penekanan terhadap fisik. 20,21

Latihan leg squat exercise merupakan salah satu model latihan untuk multi sendi yang memiliki dampak dalam meningkatkan kinerja dalam olahraga karena dapat meningkatkan kekuatan otot tubuh bagian bawah secara optimal. lebih efektif latihan beban yang melibatkan multi sendi dalam proses mengembangkan biomotor dan berdampak pada peningkatan performa keterampilan ketika berolahraga dibandingkan latihan sendi tunggal. ${ }^{21,22}$ Gerakan leg squat exercise akan mengakibatkan tubuh mengangkat beban yang lebih berat dengan posisi jongkok karena menggunakan beban luar dan berat badan sendiri. Berlatih meningkatkan kekuatan otot tungkai dengan cara jongkok-berdiri dalam gerakan leg squat exercise secara berulang maka akan mendapatkan hasil yang optimal dalam peningkatan kekuatan otot tungkai. Pelatihan leg squat exercise meningkatkan kekuatan dan volume otot grup quadriceps dan hamstring secara signifikan dan berpengaruh terhadap peningkatan hypertrophy pada otot tungkai. ${ }^{23-25}$

Terjadinya hypertrophy otot merupakan akibat myofibril bertambah pada setiap serabut otot, densitas (kepadatan) kapiler meningkat pada setiap serabut otot, jumlah protein meningkat, dan jumlah serabut otot bertambah. Hypertrophy serat otot akan mengalami satu atau lebih perubahan berikut ini: (a) jumlah dan ukuran myofibril perserat otot meningkat; (b) jumlah protein kontraktil dan partikel dalam filament myosin meningkat; (c) densitas kapiler per-fiber meningkat; (d) jumlah dan kekuatan connective, tendon, dan ligament meningkat; dan (e) jumlah serat otot meningkat. ${ }^{21,26}$ Terjadinya hypertrophy terhadap individu yang melakukan latihan dengan menggunakan beban akan menyebabkan otot putih bertambah besar kira-kira $45 \%$ dibandingkan dengan individu yang melakukan latihan tanpa menggunakan beban. ${ }^{27}$

Hypertrophy otot terjadi dikarenakan terjadi tiga rangsangan yang variatif yakni ketegangan mekanik, kerusakan otot, dan tekanan metabolik. individu yang memiliki lebih banyak serat otot, maka ototnya akan cenderung lebih besar dan lebih kuat dibanding yang individu yang memiliki serat otot lebih sedikit.7,26

\section{Pelatihan Leg Squat Exercise Lebih Meningkatkan Kekuatan Otot Tungkai daripada Pelatihan Lari 100 Meter}

Latihan leg squat exercise memiliki pengaruh yang lebih besar dan signifikan terhadap peningkatan kekuatan otot dibandingkan dengan latihan lari 100 meter sebagai latihan kontrol. Hal ini disebabkan karena banyaknya serat otot yang bekerja, dan semakin banyak sistem saraf dan biokimia tubuh yang berkembang saat latihan leg squat exercise, sehingga tenaga otot yang dikerahkan akan semakin besar dan berdampak pada semakin baiknya peningkatan kekuatan otot. ${ }^{28}$

Upaya untuk tercapainya prestasi yang optimal, diperlukan kekuatan otot. Jika menginginkan kekuatan otot yang optimal maka diperlukan latihan dalam pembentukkan komponen biomotor yang diperlukan oleh komponen fisik. Program latihan dengan menggunakan beban pemberat dari luar tubuh seperti latihan leg squat exercise yang menggunakan dumbbell atau barbell akan mempercepat proses terjadinya hypertrophy pada otot. Hypertropy pada otot menyebabkan massa otot meningkat dan berbanding lurus dengan kekuatan otot yang dihasilkan. . $^{15,24}$

Pencapain kekuatan otot yang maksimal dipengaruhi oleh beberapa faktor, yakni: (1) banyaknya motor unit yang terlibat (reqruitment), (2) banyaknya motor unit yang terstimulasi (rate coding), (3) banyaknya motor unit yang tersinkronisasi, (4) siklus pemendekan pada saat peregangan otot, (5) derajat inhibisi pada saraf otot, (6) jenis pada serabut otot, (7) dan derajat hypertrophy pada otot. ${ }^{29}$

Dibandingkan dengan latihan lari 100 meter, pelatihan leg squat exercise lebih memfokuskan tungkai sebagai aspek yang ingin dilatih. Berlatih dengan cara jongkok-berdiri ditambah dengan menggunakan beban selain beban tubuh dan dilakukan secara berulang-ulang, akan lebih baik dalam meningkatkan kekuatan otot tungkai dibandingkan dengan latihan yang hanya mengandalkan tekanan kaki. ${ }^{23}$

\section{SIMPULAN}

Berdasarkan pada penelitian yang telah dilakukan, dapat disimpulkan bahwa:

1. Pelatihan lari 100 meter yang dilakukan 2 kali dalam seminggu selama 4 minggu meningkatkan kekuatan otot tungkai pada pemain bulutangkis di GOR Porwaja Denpasar.

2. Pelatihan leg squat exercise yang dilakukan 2 kali dalam seminggu selama 4 minggu meningkatkan kekuatan otot tungkai pada pemain bulutangkis di GOR Porwaja Denpasar.

3. Pelatihan leg squat exercise yang dilakukan 2 kali dalam seminggu selama 4 minggu lebih efektif meningkatkan kekuatan otot tungkai dibandingkan pelatihan lari 100 meter pada pemain bulutangkis di GOR Porwaja Denpasar.

\section{DAFTAR PUSTAKA}

1. Hasruddin H. Kontribusi Daya Ledak Tungkai Dan Kecepatan Lari Dengan Kemampuan Lompat Jauh. Cendekia: Jurnal IImiah Pendidikan. 2019;7(1):25-32.

2. Nursal A. Pengaruh Latihan Shadow Terhadap Kelincahan Pemain Bulutangkis P.B Sinar Muda Kabupaten Muaro Jambi. Jambi: Fakultas Keguruan dan Ilmu Pendidikan Universitas Jambi; 2013.

3. Raka Juang BR. Analisis Kelebihan dan Kelemahan Keterampilan Teknik Bermain Bulutangkis pada Pemain Tunggal Putra Terbaik Indonesia Tahun 2014. Jurnal Kesehatan Olahraga. 2015;3(1):109-117. 
4. Sapta KP. Kepelatihan Bulutangkis Modern. Yuma Pustaka: Surakarta; 2010.

5. Pratama IR, Nasuka N, Hadi H. Pengaruh Latihan Plyometrics Terhadap Peningkatan Kecepatan, Kelincahan, dan Vo2max. Unnes Journal of Sport Sciences. 2015;4(2).

6. Kusnaidi I. Hubungan Explosive Power Otot Tungkai Dengan Ketepatan Smash Pada Pemain Bulu Tangkis Galaxi Tanjung Uban. Riau: Universitas Riau; 2015.

7. Schoenfeld BJ. Squatting Kinematics and Kinetics and Their Application to Exercise Performance. National Strength and Conditioning Association Unauthorized. Global Fitness Services: Scarsdale, New York; 2010.

8. Rossi FE, Schoenfeld BJ, Ocetnik S, Young J, Vigotsky A, Contreras B, Krieger JW, Miller MG, Cholewa J. Strength, body composition, and functional outcomes in the squat versus leg press exercises. J Sports Med Phys Fitness. 2018;58(3):263-70.

9. Pujianto A. Profil Kondisi Fisik dan Keterampilan Teknik Dasar Atlet Tenis Meja Usia Dini di Kota Semarang. Journal of Physical Education Health and Sport. 2015;2(1):38-42.

10. Lesmana, Syahmirza Indra. Perbedaan Pengaruh Metode Latihan Beban terhadap Kekuatan dan Daya Tahan Otot Biceps Brachialis ditinjau dari Perbedaan Gender (Studi Komparasi Pemberian Latihan Beban Metode Delorme dan Metode Oxford pada Mahasiswa Fakultas IImu Kesehatan dan Fisioterapi). Jakarta; 2012.

11. Tang A. Pengaruh Latihan Periode Persiapan Umum Pon terhadap Perubahan Daya Ledak Otot Atlet Kontingen Bayangan Pon XIX 2016 Koni Sulawesi Selatan. Media Kesehatan Politeknik Kesehatan Makassar. 2018;11(2):738.

12. Utomo B, Wahyono Y, Takarini N. Peningkatan Kekuatan, Fleksibilitas Dan Keseimbangan Otot Lanjut Usia Melalui Senam Mandiri. Interest: Jurnal IImu Kesehatan. 2012;1(2).

13. Pradana, A. Hubungan Antara Indeks Massa Tubuh (Imt) Dengan Nilai Lemak Viseral (Studi Kasus Pada Mahasiswa Kedokteran Undip). Jurnal Kedokteran Diponegoro. 2014;3(1).

14. Sherwood L. Fisiologi Manusia Dari Sel ke Sistem. Edisi 6. Jakarta: EGC; 2012.

15. Guyton AC, Hall JE. Buku Ajar Fisiologi Kedokteran. Edisi 12. Jakarta: EGC; 2014.

16. Murray RK, Granner DK, Mayes PA, Rodwell VW. Biokimia Harper. Edisi 27. Jakarta: EGC; 2013.

17. Greig CA, Jones DA. Muscle physiology and contraction. Surgery (Oxford). 2013;31(4):147-54.

18. Nugraha MH, Wahyuni N, Muliarta IM. Pelatihan 12 Balance Exercise Lebih Meningkatkan Keseimbangan Dinamis Daripada Balance Strategy Exercise Pada Lansia Di Banjar Bumi Shanti, Desa Dauh Puri Kelod, Kecamatan Denpasar Barat. Majalah Ilmiah Fisioterapi Indonesia. 2016;1(1).

19. Giriwijoyo S. Ilmu Faal Olahraga (Fisiologi Olahraga). Bandung: Remaja Rosdakarya; 2007.

20. Riadi, Mastur. Raih Kebugaran Jasmani Melalui Latihan Beban (Weight Training). Mataram: Insitut Keguruan IImu Pendidikan Mataram; 2010.

21. Bompa TO dan Haff GG. Periodization Theory and Methodology of Training. United States: Human Kinetics; 2009.

22. Fahey TD. Weight Training Basics. USA: The McGraw-Hill Companies, Inc; 2005.

23. Nala N. Prinsip Pelatihan Fisik Olahraga. Denpasar: Program Pascasarjana Studi Fisiologi Olahraga Universitas Udayana Denpasar. 1998.

24. Sukadiyanto. Pengantar Teori dan Metodologi Melatih Fisik. Yogyakarta: CV. Lubuk Agung; 2011.

25. Rachman A. Pengaruh latihan squat dan leg press terhadap strength dan hypertrophy otot tungkai. Multilateral Jurnal Pendidikan Jasmani dan Olahraga. 2016;13(2): 88-102.

26. Gafur A. Kontribusi kelincahan dan kelentukan pergelangan tangan terhadap kemampuan dribbling pada pemain bola basket. Multilateral Jurnal Pendidikan Jasmani dan Olahraga. 2016;13(2):73-87.

27. McArdle WD. Exercise Physiology: Energy, Nutrition, and Human Performance. $4^{\text {th }}$ Edition. USA: Williams and Wilkins; 2006.

28. Baechle TR dan Groves BR. Weight Training Step to Success. Jakarta: PT. Raja Grafindo Persada; 2007.

29. Hoeger WWK dan Hoeger SA. Lifetime Physical Fitness and Wellness: A Personalized Program. $10^{\text {th }}$ Ed. USA; Wadswoeth, Cengage Learning; 2009. 